Annals of Plant and Soil Research 22(4): 432-436 (2020)

https://doi.org/10.47815/apsr.2020.10017

\title{
Productivity and soil fertility of rainfed lowland rice (Oryza sativa) as influenced by establishment and weed management
}

\section{KEVIZHALHOU KUOTSU* AND AVANISH PRAKASH SINGH}

\author{
Department of Agronomy, School of Agricultural Sciences and Rural Development, Nagaland University, \\ Medziphema - 797106, Nagaland
}

Received: July, 2020; Revised accepted; September, 2020

\begin{abstract}
Field experiments were conducted during kharif season of 2016 and 2017 at the experimental farm of SASRD, Nagaland University, Medziphema to evaluate the effect of establishment methods and weed management on productivity, nutrient uptake, nutrient harvest index (NHI) and residual soil fertility of rainfed lowland rice. Three establishment techniques and six weed management practices were evaluated in split plot design with three replications. Results revealed higher grain $\left(4.24 t \mathrm{ha}^{-1}\right)$ and straw $\left(5.88 \mathrm{t} \mathrm{ha} \mathrm{a}^{-1}\right)$ yield, nutrient uptake by grain (53.1, 13.8 and $10.7 \mathrm{~kg} \mathrm{NPK} \mathrm{ha}^{-1}$ ) and straw (32.3, 6.2 and $48.8 \mathrm{~kg} \mathrm{NPK} \mathrm{ha}{ }^{-1}$ ); available nutrients in post harvest soil (332.5, 20.7 and $\left.12.3 \mathrm{~kg} \mathrm{NPK} \mathrm{ha}^{-1}\right)$ under system of rice intensification (SRI) whereas conventionally transplanted rice (CTR) recorded least values. Minimum weed dry matter $\left(158.4 \mathrm{~g} \mathrm{~m}^{-2}\right)$ and nutrient depletion (11.3, 1.9 and $19.9 \mathrm{~kg} \mathrm{NPK} \mathrm{ha}^{-1}$ ) was recorded in integrated crop management (ICM) while maximum was observed in SRI. Among the weed management methods, significantly lower weed dry weight (103.4 $\left.\mathrm{g} \mathrm{m}^{-2}\right)$, nutrient depletion $\left(7.4,1.3\right.$ and $\left.12.9 \mathrm{~kg} \mathrm{NPK} \mathrm{ha}^{-1}\right)$ and higher grain $\left(4.59 \mathrm{t} \mathrm{ha}^{-1}\right)$ and straw $\left(6.30 \mathrm{t} \mathrm{ha}^{-1}\right.$ ) yield was observed under hand weeding (HW) twice at 20 and 40 days after transplanting (DAT). Nutrient depletion by grasses was observed to be higher as compared to sedges and broad leaved weeds. Weed control increased nutrient uptake by rice and decreased nutrient uptake by weeds. Hand weeding at 20 and 40 DAT recorded highest grain yield which was $81 \%$ higher over weedy check.
\end{abstract}

Keywords: Establishment method, NHI, rainfed lowland rice, weed management

\section{INTRODUCTION}

Rice is the staple food and major crop of the people of Nagaland with $71.14 \%$ of its population living in rural areas and highly dependent on agriculture. Monsoon-based monocropping of rice is prevalent in Nagaland mainly due to lack of short-duration varieties and secondly, due to low temperature during postkharif season which results in spikelet sterility. Nagaland with an area of 2.14 lakh ha under rice production and an average productivity of $2.50 \mathrm{t}$ ha $^{-1}$ still imports rice to feed her growing population (Anonymous, 2019). Establishment methods such as System of Rice Intensification (SRI) and Integrated Crop Management (ICM) are gaining popularity among the farming communities. However, the case is not so in Nagaland and majority of farmers still follow the conventional method. Though reports suggest that the yield of rice could be enhanced by adopting SRI and ICM method of cultivation (Das et al. 2014) there are also contradictory results and very less study has been carried out in Nagaland till date. Owing to erratic rainfall and the acidic nature of the soil resulting in imbalanced supply of nutrients to crops coupled with weed problem, there are vast reductions in crop yields which were reported to vary from 20$50 \%$ depending upon the various conditions of rice culture in Meghalaya (Islam and Kalita 2015). Weeds remove a large amount of nutrients from soil in addition to competing with the crop for space, moisture and light. Estimate shows that weeds can deprive the crops by $47 \%$ $\mathrm{N}, 42 \% \mathrm{P}, 50 \% \mathrm{~K}, 39 \% \mathrm{Ca}$ and $24 \% \mathrm{Mg}$ of their nutrient uptake and reduce the yield potential in addition to harbouring crop pests as well as diseases (Kabdal et al. 2018). So, there is a need to reduce the weed competition starting from crop emergence up to harvest and to develop a cost effective weed management technique. The usages of herbicides in general and molecules in particular which are effective even in small amounts over large areas is still new to the region and a lot of work still needs to be done. The present investigation was therefore undertaken to study the effect of establishment and weed management methods on productivity of rainfed lowland rice and soil fertility status. 


\section{MATERIALS AND METHODS}

The experiment was conducted at the experimental research farm of the School of Agricultural Sciences and Rural Development (SASRD), Medziphema campus, Nagaland University during the kharif season of 2016 and 2017 located in the foothill of Nagaland with humid sub-tropical climate and an altitude of 310 $\mathrm{m}$ above mean sea level. The soil of the experimental site was clay-loam in texture, acidic in reaction ( $\mathrm{pH} 5.72$ ), organic carbon $14.2 \mathrm{~g} \mathrm{~kg}^{-1}$, medium in available $\mathrm{N}$ (338 $\mathrm{kg} \mathrm{ha}^{-1}$ ) and available $P\left(17.9 \mathrm{~kg} \mathrm{ha}^{-1}\right)$ and low in available $\mathrm{K}$ $\left(121 \mathrm{~kg} \mathrm{ha}^{-1}\right)$. Fertilizer dose of $80 \mathrm{~kg} \mathrm{~N}+60 \mathrm{~kg}$ $\mathrm{P}_{2} \mathrm{O}_{5}+40 \mathrm{~kg} \mathrm{~K}_{2} \mathrm{O} \mathrm{ha}^{-1}$ in the form of urea, single superphosphate and muriate of potash were applied as common dose in all the plots for both the years. The experiment was replicated thrice in split-plot design with three crop establishment techniques, viz. system of rice intensification (SRI), integrated crop management (ICM) and conventionally transplanted rice (CTR) as the main treatments and six weed management practices, viz. weedy check $\left(\mathrm{W}_{1}\right)$, hand weeding at 20 and 40 days after transplanting $\left(\mathrm{W}_{2}\right)$, bispyribac sodium @ 0.25 I ha ${ }^{-1}\left(\mathrm{~W}_{3}\right)$, pretilachlor followed by hand weeding at 40 DAT $\left(\mathrm{W}_{4}\right)$, pretilachlor at 3 DAT $f b$ bispyribac sodium at 40 DAT $\left(\mathrm{W}_{5}\right)$ and cono-weeding at 20 and 40 DAT $\left(\mathrm{W}_{6}\right)$ as the sub-plot treatments. The nurseries for all the establishment methods were sown on the same day but transplanting date varied as per the requirement of different establishment methods. For SRI, 10-day-old seedling at 1 seedling hill $^{-1}$ was used with $25 \mathrm{~cm} \times 25 \mathrm{~cm}$ spacing while for ICM, 15-day-old seedlings at 2 seedlings hill $^{-1}$ were used with a spacing of 20 $\mathrm{cm} \times 20 \mathrm{~cm}$ and for CTR, 30-day-old seedlings at 3 seedlings hill $^{-1}$ with a spacing of $20 \mathrm{~cm} \times 10$ $\mathrm{cm}$ was followed. The nursery for SRI and ICM was prepared using a modified mat nursery (MMN) method. However, for CTR, the conventional method was used with $60 \mathrm{~kg}$ seed $\mathrm{ha}^{-1}, 500 \mathrm{~m}^{2}$ nursery area, raised bed of $1 \mathrm{~m}$ width and $0.15 \mathrm{~m}$ height. The three establishment methods (SRI, ICM and CTR) were compared with each other considering respective package of practices as part of treatments. Rice variety RCM 9 was used as test variety for this experiment. All other recommended package of practices was followed and weed samples were collected from a $1 \mathrm{~m}^{2}$ quadrant. Soil samples were analysed for alkaline permanganate oxidizable $\mathrm{N}, 0.5 \mathrm{M}$ $\begin{array}{llllll}\mathrm{NaHCO}_{3} & \text { extractable } \mathrm{P} \text { and } 1 & \mathrm{~N}^{2} & \mathrm{NH}_{4} \mathrm{O} & \mathrm{Ac}\end{array}$ exchangeable $\mathrm{K}$ while rice grain and straw and weed samples were analysed for $\mathrm{N}$ using microKjeldahl method. Phosphorus and $\mathrm{K}$ contents were deter in mind sulphuric-nitric-perchloric acid digest as per procedures described by Prasad et al. (2006). Nutrient uptake was computed by multiplying the respective yield/weed dry matter with nutrient concentrations. Nutrient harvest index (NHI) was calculated by the formula

$\mathrm{NHI}=\underline{\text { Uptake of a particular nutrient by grain }} \times 100$ straw Total uptake of that particular nutrient by grain and

Data obtained from the experiment were statistically analysed using standard procedures of ANOVA at $5 \%$ level of significance.

\section{RESULTS AND DISCUSSION}

\section{Nutrient depletion by weeds}

Pooled results (Table 1) showed that nitrogen $\left(11.3 \mathrm{~kg} \mathrm{ha}^{-1}\right)$, phosphorus $\left(1.92 \mathrm{~kg} \mathrm{ha}^{-}\right.$ $\left.{ }^{1}\right)$ and potassium $\left(19.9 \mathrm{~kg} \mathrm{ha}^{-1}\right.$ ) depletion by weeds was minimum in ICM which was significantly lower than the other establishment methods. SRI, on the other hand, recorded the maximum total $\mathrm{N}$ uptake $\left(16.3 \mathrm{~kg} \mathrm{ha}^{-1}\right)$ by weeds. Higher weed dry matter was recorded in SRI as compared to ICM and CTR ultimately led to higher depletion of nitrogen. Parameswari and Srinivas (2014) also reported higher uptake of nutrients in SRI as compared to conventional transplanting. The uptake of NPK was higher in grasses followed by sedges and broad leaved weeds and can be attributed to higher density and biomass in comparison to sedges or broad leaved weeds which is in conformity to the findings of Singh and Singh (2010). Minimum depletion in ICM may be attributed to lower weed dry matter. Among weed management methods, minimum depletion of $\mathrm{N}, \mathrm{P}$ and $\mathrm{K}$ was recorded in hand weeding twice at 20 and 40 DAT while maximum was recorded in weedy check. Excessive growth in weedy check may have led to higher depletion as it prevented the rice plants from absorbing adequate amount of nutrients. Weed management practices were also observed to increase nutrient uptake by rice and decrease uptake by weeds. Similar results were reported by Islam and Kalita (2015). 
Table 1: Effect of establishment and weed management methods on total weed dry matter $\left(\mathrm{kg} \mathrm{ha}^{-1}\right)$ and nutrient depletion by weeds at 60 DAT (pooled data of 2 years)

\begin{tabular}{|c|c|c|c|c|c|c|c|c|c|c|c|c|c|}
\hline \multirow{3}{*}{ Treatments } & \multirow{3}{*}{$\begin{array}{c}\text { Weed } \\
\text { biomass } \\
\left(\mathrm{g} \mathrm{m}^{-2}\right)\end{array}$} & \multicolumn{12}{|c|}{ Nutrient depletion by weeds $\left(\mathrm{kg} \mathrm{ha}^{-1}\right)$} \\
\hline & & \multicolumn{3}{|c|}{ Grasses } & \multicolumn{3}{|c|}{ Sedges } & \multicolumn{3}{|c|}{ Broad leaved weeds } & \multicolumn{3}{|c|}{ Total } \\
\hline & & $\mathrm{N}$ & $\mathrm{P}$ & $\mathrm{K}$ & $\mathrm{N}$ & $P$ & $\mathrm{~K}$ & $\mathrm{~N}$ & $\mathrm{P}$ & $\mathrm{K}$ & $\mathrm{N}$ & $\mathrm{P}$ & $\mathrm{K}$ \\
\hline \multicolumn{14}{|c|}{ Rice establishment methods } \\
\hline SRI & 226.8 & 6.5 & 1.07 & 10.3 & 5.4 & 0.88 & 9.7 & 4. & 0.79 & 8.6 & 16.3 & 2.8 & 28.5 \\
\hline ICM & 158.4 & 4.4 & 0.77 & 7.6 & 4.1 & 0.67 & 7.0 & 2.8 & 0.48 & 5.4 & 11.3 & 1.9 & 19.9 \\
\hline CTR & & 5.7 & 0.94 & 9.7 & 4.9 & 0.80 & 8.3 & 3.3 & 0.61 & 6.3 & 13.9 & 2.4 & 24.3 \\
\hline SEm \pm & 5.85 & 0.06 & 0.01 & 0.17 & 0.11 & 0.01 & 0.16 & 0.03 & 0.12 & 0.13 & 0.27 & 0.04 & 0.51 \\
\hline $\mathrm{CD}(P=0.05)$ & & 0.21 & 0.04 & 0.61 & 0.32 & 0.04 & 0.51 & 0.11 & 0.38 & 0.42 & 0.87 & 0.14 & 1.66 \\
\hline \multicolumn{14}{|c|}{ Weed management methods } \\
\hline$W_{1}$ & 411.1 & 12.7 & 2.10 & 21.2 & 9.2 & 1.60 & 16.5 & 7. & 1.30 & 13.9 & 29.5 & 5.0 & 51.6 \\
\hline$W_{2}$ & 103.4 & 3.1 & 0.51 & 5.2 & 2.7 & 0.44 & 4.8 & 1.6 & 0.30 & 2.9 & 7.40 & 1.3 & 12.9 \\
\hline$W_{3}$ & 193.1 & 5.0 & 0.89 & 9.2 & 4.6 & 0.78 & 8.2 & 4.1 & 0.71 & 6.8 & 13.8 & 2.4 & 24.2 \\
\hline$W_{4}$ & 121.2 & 3.3 & 0.56 & 6.1 & 2.9 & 0.47 & 5.0 & 2.5 & 0.44 & 4.1 & 8.68 & 1.5 & 15.2 \\
\hline$W_{5}$ & 152.2 & 4.4 & 0.74 & 8.0 & 3.8 & 0.63 & 5.9 & 2.7 & 0.48 & 5.2 & 10.9 & 1.9 & 19.1 \\
\hline$W_{6}$ & 176.6 & 4.7 & 0.75 & 8.7 & 4.1 & 0.71 & 7.1 & 3.9 & 0.69 & 6.4 & 12.7 & 2.2 & 22.2 \\
\hline SEm \pm & 8.10 & 0.16 & 0.03 & 0.37 & 0.17 & 0.02 & 0.34 & 0.06 & 0.17 & 0.22 & 0.54 & 0.08 & 0.94 \\
\hline $\mathrm{CD}(P=0.05)$ & 22.9 & 0.42 & 0.07 & 0.98 & 0.54 & 0.07 & 0.94 & 0.20 & 0.55 & 0.76 & 1.52 & 0.23 & 2.66 \\
\hline
\end{tabular}

\section{Productivity}

Pooled data of two years (Table 2) revealed higher grain $\left(4.24 \mathrm{t} \mathrm{ha}^{-1}\right)$ as well as straw yield $\left(5.88 \mathrm{t} \mathrm{ha}^{-1}\right)$ under SRI and was comparable to ICM and significant over CTR. Usage of younger seedlings, wider spacing, aerobic conditions, avoiding transplanting shock and planting of seedlings singly before third phyllochron leading to quicker tiller initiation could be reason for higher yields under SRI. Because seedlings are planted singly and with wider spacing in SRI, there is enhanced root development which supports more yield because tillering and grain filling increases with wider spacing. The larger root volume and higher yield attributes with higher grain weight may have contributed to higher yields (Duttarganvi et al. 2016). Kumar et al. (2015) also reported similar results. Hand weeding at 20 and 40 DAT recorded significantly higher yields among the weed management methods. All weed management practices recorded significantly higher yield compared to weedycheck. The higher yield in weed control treatments could be due to less competition intreated

Table 2: Effect of establishment and weed management methods on productivity, nutrient uptake and nutrient harvest index (pooled data of 2 years)

\begin{tabular}{|c|c|c|c|c|c|c|c|c|c|c|c|c|c|c|}
\hline \multirow{3}{*}{ Treatments } & \multirow{2}{*}{\multicolumn{2}{|c|}{ Yield (t ha ${ }^{-1}$ ) }} & \multicolumn{9}{|c|}{ Nutrient uptake $\left(\mathrm{kg} \mathrm{ha}^{-1}\right)$} & \multirow{2}{*}{\multicolumn{3}{|c|}{$\begin{array}{l}\text { Nutrient harvest } \\
\text { index }(\%)\end{array}$}} \\
\hline & & & \multicolumn{3}{|c|}{ Grain } & \multicolumn{3}{|c|}{ Straw } & \multicolumn{3}{|c|}{ Total } & & & \\
\hline & Grain & Straw & $\mathrm{N}$ & $\mathrm{P}$ & $\mathrm{K}$ & $\mathrm{N}$ & $P$ & $\mathrm{~K}$ & $\mathrm{~N}$ & $P$ & $\mathrm{~K}$ & $\mathrm{NHI}$ & $\mathrm{PHI}$ & $\mathrm{KHI}$ \\
\hline \multicolumn{15}{|c|}{ Rice establishment methods } \\
\hline & 4.24 & 5.88 & 53.1 & 13.8 & 10.7 & 32.3 & 6.28 & 48.8 & 85.3 & 20.1 & 59.5 & 62.2 & 68.8 & 17.9 \\
\hline IC & $4 .($ & & 50.6 & 13.1 & 10.1 & 30.9 & 5.87 & 44.6 & 1.6 & 18.9 & 54.7 & 62.1 & 3.9 & 18.5 \\
\hline & & & 45.2 & 10.9 & 9.1 & 29.1 & & 40.1 & 1.5 & 16.5 & 49.2 & 60.8 & 6 & 18.4 \\
\hline & & & 1.80 & 0.28 & 0.23 & 0.69 & & 0.95 & 2.02 & 0.49 & 1 & 1.28 & 1.29 & 0.53 \\
\hline $\mathrm{CD}(P=0.05$ & 0.22 & 0.21 & 5.87 & 0.90 & 0.7 & 2.25 & & 3.08 & 6.45 & 1.57 & 3.2 & OC & & NS \\
\hline \multicolumn{15}{|c|}{ Weed management methods } \\
\hline & 2.53 & 4.20 & 30.7 & 7.14 & 6.23 & 19.8 & 3.08 & 22.2 & 50.5 & 10.2 & 28.4 & 60.8 & 69.9 & 21.9 \\
\hline & 4.5 & & 57.5 & 15.8 & 11.5 & 37.9 & 7.08 & 66.8 & 95.5 & 22.9 & 78.3 & 60.2 & 69.0 & 14.7 \\
\hline v & 4.01 & 5.88 & 51.9 & 12.9 & 10.3 & 29.0 & 5.78 & 39.4 & 80.9 & 18.7 & 49.6 & 64.1 & 69.0 & 20.7 \\
\hline$W_{4}$ & 4.32 & 6.04 & 53.9 & 14.1 & 10.9 & 34.9 & 6.62 & 50.5 & 88.8 & 20.7 & 61.4 & 60.7 & 68.1 & 17.8 \\
\hline$W_{5}$ & 4.24 & 6. & 52.9 & 13.3 & 10.6 & 33.0 & 6.52 & 47.1 & 85.9 & 19.8 & 57.7 & 61.6 & 67.1 & 18.4 \\
\hline & 4.10 & 5.8 & 51.1 & 12.5 & 10.1 & 29.9 & 6.24 & 41.1 & 80.9 & 18.7 & 51.2 & 63.1 & 66.7 & 19.7 \\
\hline $\mathrm{SE}$ & 0.12 & 0.11 & 2.6 & 0.44 & 0.44 & 1.13 & 0.31 & 1.44 & 2.64 & 0.61 & 2.19 & 1.84 & 2.21 & 0.71 \\
\hline $\mathrm{CD}(P=0.05)$ & 0.34 & 0.30 & 7.35 & 1.23 & 1.24 & 3.21 & 0.87 & 4.07 & 7.65 & 1.75 & 6.21 & NS & NS & 2.01 \\
\hline
\end{tabular}


plots as weeds were eliminated to a large extent (Lhungdim et al. 2019). Kaur and Singh (2015) also reported higher yields as well as yield attributes with hand weeding than a variety of herbicides alone or in sequential application.

\section{Uptake of nutrients by rice and nutrient harvest index}

Pooled data (Table 2) showed higher nitrogen uptake by both grain $\left(53.1 \mathrm{~kg} \mathrm{ha}^{-1}\right)$ and straw (32.3 $\left.\mathrm{kg} \mathrm{ha}^{-1}\right)$ which was significant over CTR and at par with ICM. Among the weed management methods, hand weeding at 20 and 40 DAT recorded higher $\mathrm{N}$ uptake in grain (57.3 $\mathrm{kg} \mathrm{ha}^{-1}$ ) and straw (37.9 $\mathrm{kg} \mathrm{ha}^{-1}$ ) while the minimum values were observed in weedy check for grain $\left(30.7 \mathrm{~kg} \mathrm{ha}^{-1}\right)$ and straw (19.8 $\left.\mathrm{kg} \mathrm{ha}^{-1}\right)$. The higher uptake of $\mathrm{N}$ by $\mathrm{SRI}$ and hand weeding twice at 20 and 40 DAT as compared to the other establishment and weed management methods might be due to higher grain and straw yield and not due to concentration. The present findings are in corroboration with those of Islam and Kalita (2015). Neither establishment nor weed management methods was found to have a significant effect on nitrogen harvest index. However, SRI and application of Bispyribac sodium was found to record higher values which can be attributed to more extraction of nutrients from the soil. Phosphorus uptake at harvest was higher with SRI $\left(13.1 \mathrm{~kg} \mathrm{ha}^{-1}\right)$ in grain and straw $\left(6.28 \mathrm{~kg} \mathrm{ha}^{-1}\right)$ and was at par with ICM but significant over CTR. Among the weed management methods, hand weeding at 20 and
40 DAT recorded higher values in both grain $\left(15.8 \mathrm{~kg} \mathrm{ha}^{-1}\right)$ and straw $\left(7.08 \mathrm{~kg} \mathrm{ha}^{-1}\right)$ while the minimum values of $7.14 \mathrm{~kg} \mathrm{ha}^{-1}$ and $3.08 \mathrm{~kg} \mathrm{ha}^{-1}$ were recorded in weedy check for both grain and straw respectively. The higher uptake in SRI and hand weeding may be attributed to higher yields. Enhanced root growth in SRI might also have absorbed more moisture and nutrients resulting in higher $P$ uptakes (Patel et al. 2008). Phosphorus harvest index was however not found to be significantly affected by any of the treatments. Higher uptake of $\mathrm{K}$ by both grain and straw was observed in SRI (10.7 and $48.8 \mathrm{~kg}$ ha 1) followed by ICM (10.1 and $\left.44.6 \mathrm{~kg} \mathrm{ha}^{-1}\right)$. Among the weed management methods, hand weeding at 20 and 40 DAT recorded higher $\mathrm{K}$ uptake in grain $\left(11.5 \mathrm{~kg} \mathrm{ha}^{-1}\right)$ and straw $(66.8 \mathrm{~kg}$ $\left.\mathrm{ha}^{-1}\right)$. Higher uptake may be due to better weed control leading to lower depletion of nutrients by weeds and higher uptake by rice (Parameswari and Srinivas 2014). Potassium harvest index $(\mathrm{KHI})$ was not significant for establishment methods while it was significantly higher in weedy check $(21.9 \%)$ followed by application of bispyribac sodium (20.69\%) while minimum of $14.7 \%$ was recorded in hand weeding at 20 and 40 DAT. The higher values of $\mathrm{KHI}$ in weedy check can be attributed to the higher concentration of $\mathrm{K}$ in straw as compared to grain and lower uptake by grain as yield was significantly lower. Similar results of weedy check recording higher $\mathrm{KHI}$ as compared to hand weeding twice have also been reported by Islam and Kalita (2015).

Table 3: Effect of establishment and weed management methods on residual soil fertility status after harvest (pooled data of 2 years)

\begin{tabular}{|c|c|c|c|c|c|}
\hline \multirow{2}{*}{ Treatments } & \multirow{2}{*}{$\mathrm{pH}(1: 2)$} & \multirow{2}{*}{$\begin{array}{c}\text { Organic Carbon } \\
\left(\mathrm{g} \mathrm{kg}^{-1}\right)\end{array}$} & \multicolumn{3}{|c|}{ Available nutrients $\left(\mathrm{kg} \mathrm{ha}^{-1}\right)$} \\
\hline & & & $\mathrm{N}$ & $P$ & $\mathrm{~K}$ \\
\hline \multicolumn{6}{|c|}{ Rice establishment methods } \\
\hline SRI & 5.7 & 14.3 & 332.5 & 20.7 & 123.1 \\
\hline ICM & 5.7 & 14.2 & 330.4 & 18.9 & 121.7 \\
\hline CTR & 5.7 & 14.0 & 327.3 & 17.9 & 116.8 \\
\hline SEm \pm & 0.02 & 0.4 & 5.58 & 0.26 & 1.88 \\
\hline $\mathrm{CD}(P=0.05)$ & NS & NS & NS & 0.86 & NS \\
\hline \multicolumn{6}{|c|}{ Weed management methods } \\
\hline$W_{1}$ & 5.7 & 14.2 & 318.8 & 18.4 & 116.9 \\
\hline$W_{2}$ & 5.7 & 14.7 & 342.3 & 20.1 & 123.8 \\
\hline $\mathrm{W}_{3}$ & 5.7 & 14.3 & 337.0 & 19.4 & 119.7 \\
\hline $\mathrm{W}_{4}$ & 5.7 & 14.1 & 322.2 & 18.7 & 117.9 \\
\hline$W_{5}$ & 5.8 & 14.0 & 327.1 & 19.1 & 121.7 \\
\hline $\mathrm{W}_{6}$ & 5.7 & 13.7 & 332.8 & 19.3 & 123.1 \\
\hline SEm \pm & 0.04 & 0.6 & 6.63 & 0.37 & 1.97 \\
\hline $\mathrm{CD}(P=0.05)$ & NS & NS & 18.8 & 1.04 & NS \\
\hline
\end{tabular}




\section{Residual soil fertility}

Soil organic carbon and $\mathrm{pH}$ was not affected significantly by rice establishment methods and weed management techniques (Table 3) as these parameters are not altered easily over short durations of time. The same was observed for soil available $\mathrm{K}$. The results are in corroboration with those of Das et al. (2014). Hand weeding at 20 and 40 DAT, however, left significantly higher amount of available $\mathrm{N}$ (342.3 $\mathrm{kg} \mathrm{ha}^{-1}$ ) in soil among the weed management methods. Maximum phosphorus $\left(20.7 \mathrm{~kg} \mathrm{ha}^{-1}\right)$ remained in the soil after harvest in SRI among the establishment methods followed by ICM and CTR. Alternate wetting and drying in SRI may have created better soil physicochemical conditions, which

\section{REFERENCES}

Anonymous.(2019) Nagaland Statistical Handbook, 2019.Directorate of Economics and Statistics, Nagaland Kohima.pp 28.

Das,A., Patel, D.P., Munda, G.C., Ramkrushna, G.I., Kumar, M. and Ngachan, S. V. (2014) Improving productivity, water and energy use Efficiency in lowland rice (Oryza sativa) through appropriate establishment methods and nutrient management practices in the mid-altitude of north-east India. Experimental Agriculture 50 (3): 353-375.

Duttarganvi, S., Kumar, R.M., Desai, B.K., Pujari, B.T., Tirupataiah, K., Koppalkar, B. G., Umesh, M.R., Naik, M.K. and Reddy, K.Y. (2016) Influence of establishment methods, irrigation water levels and weed management practices on growth and yield of rice (Oryza sativa). Indian Journal of Agronomy 61(2): 174-178.

Islam, M.M. and Kalita, D.C. (2015) Establishment methods and weed management effects on productivity and soil fertility in wetland rice (Oryza sativa L.). Journal of the Indian Society of Soil Science 63 (3): 339-346.

Kabdal, P., Pratap, T. and Yadav, V.R. (2018) Weed management in transplanted rice - a review.International Journal of Current Microbiology and Applied Sciences 7 (4): 1660-1669.

Kaur, S. and Singh, S. (2015) Bio-efficacy of different herbicides for weed control in direct-seeded rice. Indian Journal of Weed Science 47 (2): 106-109. enhanced soil biological activity and $P$ availability (Das et al. 2014). The higher residual $P$ may also be attributed to phosphorus cycling due to alternate wetting and drying compared to flooded conditions. Among weed management methods, maximum residual $P$ in soil was observed in the case of hand weeding twice at 20 and 40 DAT while minimum in weedy check. The rest of the weed management methods were observed to be at par with each other. Similar results were reported by Islam and Kalita (2015).

It may be concluded from the results that hand weeding at 20 and 40 DAT in SRI could be recommended due to its higher productivity and soil fertility as well as lower nutrient depletion over ICM and CTR for rainfed lowland conditions of Nagaland.

Kumar, S., Sinha, K.K. and Singh, D. (2015) Crop establishment, fertility and weed management practices in scented hybrid rice. Indian Journal of Weed Science 47 (2): 113-116.

Lhungdim, J., Devi, Y.S., Devi, K.N. and Chanu, Y.B. (2019) Influence of weed control techniques and establishment method on yield and economics of rainfed lowland rice. Journal of Crop and Weed 15 (1): 121126.

Parameswari, Y. S. and Srinivas, A. (2014) Influence of weed management practices on nutrient uptake and productivity of rice under different methods of crop establishment. Journal of Rice Research 7 (1\&2): 77-86.

Patel, D.P., Das, A., Munda, G.C., Ghosh, P.K., Ngachan, S.V., Kumar, R. and Saha, R. (2008) SRI and ICM rice culture for water economy and higher productivity. Research Bulletin No. 68. ICAR RC for NEHR, Umiam, pp. 1-28.

Singh, M. and Singh R.P. (2010) Influence of crop establishment methods and weed management practices on yield and economics of direct-seeded rice (Oryza sativa). Indian Journal of Agronomy 55 (3): 224-229.

Prasad, R., Shivay, Y.S., Kumar, D. and Sharma, S.N. (2006) Learning by Doing Exercises in Soil Fertility, 68 pp. Division of Agronomy, Indian Agricultural Research Institute, New Delhi. 